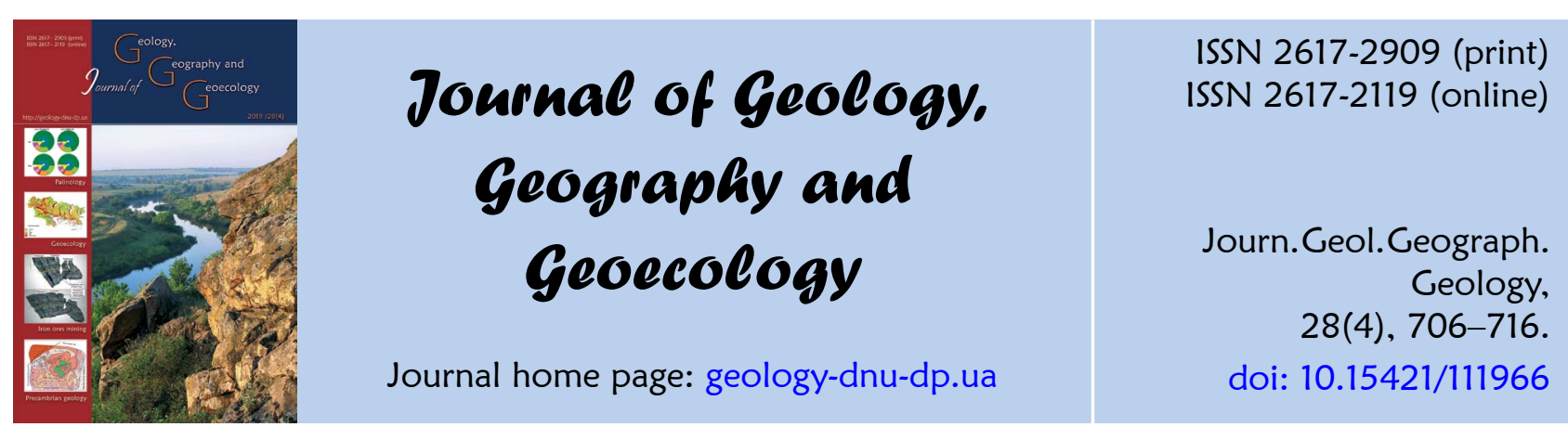

Mykhailo V. Petlovanyi, Vladislav V. Ruskykh, Serhiy A. Zubko

Journ. Geol. Geograph. Geoecology, 28(4), 706-716.

\title{
Peculiarities of the underground mining of high-grade iron ores in anomalous geological conditions
}

\author{
Mykhailo V. Petlovanyi ${ }^{1}$,Vladislav V. Ruskykh ${ }^{1}$, Serhiy A. Zubko² \\ ${ }^{1}$ Underground Mining Department, Dnipro University of Technology, Dnipro, Ukraine, petlyovany@ukr.net \\ ${ }^{2}$ PJSC “Zaporizhzhia Iron Ore Plant”, Mala Bilozerka, Ukraine
}

Received in revised form: 10.03 .2019

Accepted: 03.09.2019
Received: 22.02 .2019

Abstract. This paper is dedicated to research into the geological peculiarities, shape of the ore body and the occurrence of the host rocks in the hanging wall of the Pivdenno-Bilozerske deposit, as well as their influence on the degrees and quality of high-grade iron ore extraction. It is noted that in the interval of $480-840 \mathrm{~m}$ depths, a decrease is observed in the stability of the natural and technogenic massif, which is caused by the increase in rock pressure with depth, the influence of blasting operations on the massif and the difference in geological conditions. This has led to the collapse of hanging wall rocks and backfill into the mined-out space of chambers in certain areas of the deposit, the dilution of the ore and deterioration of the operational state of the underground mine workings. Attention is focused on the causes and peculiarities of consequences of the collapse of the hanging wall rocks during ore mining, which reduce the technical and-economic indexes of the ore extraction from the chambers. A 3D-model of an ore deposit with complex structural framework has been developed, which makes it possible to visually observe in axonometric projection the geological peculiarities and the shape of the ore body. The parameters have been studied of mining chambers in the $640-740 \mathrm{~m}$ floor under different changing geological conditions of the ore deposit and hanging wall rocks occurrence - the northern, central and southern parts. The difference in the iron content in the mined ore relative to the initial iron content in the massif has been defined as an indicative criterion of the influence of changing conditions on the production quality. The reasons have been revealed which contribute to the collapse of the rocks and the subsequent decrease in the iron content of the mined ore in ore deposit areas differing by their characteristics. It has been determined that within the central and half of the southern ore deposit parts with a length of $600 \mathrm{~m}$, an anomalous geological zone is formed, the manifestation of which will be increased with the depth of mining. It was noted that within this zone, with the highest intensity and density of collapse of hanging wall rocks, the influence of decrease in the slope angle and change in the strike direction are of greatest priority, and such geological factors as a decrease in hardness, rock morphology, deposit thickness increase this influence significantly. To solve the problems of the hanging wall rocks' stability, it is recommended to study the nature and direction of action of gravity forces on the stope chambers in the northern, central and southern parts, as well to search for scientific solutions in regard to changes in the geometric shapes of stope chambers and their spatial location, improving the order of reserves mining in terms of the ore deposit area, the rational order of breaking-out ore reserves in the chambers with changing mining and geological conditions of the fields' development.

Keywords:iron-ore deposits, dilution, iron content, collapse of rocks, hanging wall, geological structure, angle of slope and strike

\section{Особливості підземної розробки багатих залізних руд в умовах аномального геологічного середовища}

\author{
М. Петльований', В. Руських ${ }^{1}$, С. Зубко ${ }^{2}$ \\ ${ }^{1}$ Національний технічний університет “Дніпровська політехніка”, Дніпро, Україна, реtlyovany@ukr.net \\ ${ }^{2}$ ПIППрАТ “Запорізький залізорудний комбінат”, Дніпрорудне, Украӥна
}

Анотація. Стаття присвячена дослідженню геологічних особливостей і форми залягання рудного тіла й вміщуючих порід висячого боку Південно-Білозерського родовища та їх впливу на показники і якість вилучення багатих залізних руд. Відзначено, що в інтервалі глибин 480 - 840 м спостерігається зниження стійкості природно-техногенного масиву, викликане гірським тиском, що посилюється з глибиною, впливом на масив вибухових робіт, відмінністю геологічних умов, що призвело до обвалення порід висячого боку та закладення у вироблений простір камер на певних ділянках родовища, засмічення руди й погіршення експлуатаційного стану підземних гірничих виробок. Акцентовано увагу на причини та особливості наслідків обвалення порід висячого боку при видобутку руди, що погіршують техніко-економічні показники видобутку руди з камер. 
Побудована об'ємна 3D-модель складнопобудованого рудного покладу, що дозволяє наочно спостерігати в аксонометрії геологічні особливості та форму залягання рудного тіла. Досліджено показники відпрацювання камер у поверсі 640-740 м у різних мінливих геологічних умовахрудного покладуі порід висячого боку - північній, центральній та південній частинах. Як критерій-показник впливу умов, що змінюються, на якість видобутку обрана різниця вмісту заліза у видобутій руді по відношенню до вихідного вмісту заліза в масиві. Виявлено причини, що сприяють обваленню порід і подальшому зниженню вмісту заліза у видобутій руді в різних за характеристиками ділянках рудного покладу. Визначено, що у межах центральної та половини південної частинрудного покладу довжиною 600 м формується аномальна геологічна зона, характер прояву якої буде зростати з глибиною розробки. Відзначено, що в цій зоні, де найбільш висока інтенсивність і щільність обвалень порід висячого боку, вплив зменшення кута падіння та зміни напрямку простягання маютьпереважаюче значення, а такі геологічні фактори як зниження міцності, морфології порід, потужності покладу значно посилюють цей вплив. Рекомендовано для вирішення проблем стійкості порід висячого боку вивчити характер і напрям дії сил гравітації на очисні камери як у північній, так і в центральній з південною частинами, а пошук наукових рішень вести відносно зміни геометричних форм очисних камер та їх просторового розташування, вдосконалення порядку відпрацювання запасів за площею рудного покладу, раціонального порядку відбиваннязапасів руди в камерах при гірничо-геологічних умовах розробки родовищ, що змінюються.

Ключові слова: залізорудні родовища, засмічення, вміст заліза, обвалення порід, висячий бік, геологічна будова

Introduction. Ukraine holds the first place in the world in terms of geological reserves of iron ores, which are assessed at 30 billion tons, and per pure iron content it holds the fourth place after Russia, Brazil and Australia (Peregudov, Gritsina, \& Dragun, 2010; USGS, 2018). The significant iron ore reserves are concentrated mainly in the 5 largest iron-ore basins and regions - Kryvorizkyi, Kremenchutskyi, Kerchenskyi, Bilozerskyi and Pryazovskyi (Shatokha, 2015). Among the specified fields, the Bilozerskyi iron-ore region, which consists of the Pivdenno-Bilozerske, Pivnichno-Bilozerske and Pereverzivske fields, is the leader by the average iron content in the ore $(61 \%)$, the explored total geological reserves of which are 2.5 billion tons (Gnatush, 2009). Currently, the enterprise PJSC "Zaporizhzhia Iron Ore Plant" is actively developing the hematitemartite ores of the Pivdenno-Bilozerske field and the extraction of the Pereverzivske field was begun. The enterprise has introduced a highly effective chamber system of mining with the subsequent filling of the mined-out space with a consolidating mixture, which is unique among the Ukrainian iron ore deposits. This made it possible to prevent lowering of the earth surface, to improve the safety level of mining operations and the completeness of ore reserves extraction, to reduce their dilution (Kuz'menko, Furman, \&Usatyy, 2010; Kononenko, Petlovanyi, \&Zubko, 2015), as well as to recover the mining waste products in the underground space and to prevent their accumulation (Petlovanyi\&Medianyk, 2018; Petlovanyi et al., 2019).The significant volumes of smelter slags, flux production wastes and rocks refuse are recovered as a portion of the filling mixture(Kuzmenko \&Petlovanyi, 2015).

When developing the thick ore bodies of high value by means of the systems of development with consolidating backfilling, the stope and backfilling works, as a rule, are spread out over a period of time and mining is performed by a"chamber - pillar" scheme (Li, 2013; Emad, Vennes, Mitri, \& Kelly, 2014). Taking into account the high value of the ores in the Pivdenno-Bilozerske field (the iron content is more than $60 \%$ ), the production of finished products to consumers is performed without technological cycle of enrichment. Being extracted, the ore is processed at the crushing and screening plant to a certain granulometric composition,sorted by iron content and delivered by rail to the metallurgical enterprises of Ukraine and to the European Union countries. The issue of minimum ore dilution is constantly relevant for the enterprise, which is conditioned by high requirements to the mined ores' quality. The market price for iron ore is set by the iron content in it, and by the successful export and, thus, profitability. Thus, it is necessary to maintain quality characteristics in order to avoid losing competitiveness of the iron ore in the market (Fu, 2018).

Despite the use of an effective mining system with a consolidating backfill, when developing the ore reserves in the range of $480-840 \mathrm{~m}$ depths, serious problems of the natural and technogenic massif stability have arisen, caused by the increase in rock pressure with depth, the influence of blasting operations and the difference in geological conditions. This leads to the collapse of rocks and backfill into the minedout space of chambers in certain areas of the deposit. This results in the ore's dilution and, consequently, an increase in production costs, which is studied in a number of scientific works (Forster, Milne, \& Pop, 2007; Henning \& Mitri, 2007; Urli \& Esmaieli, 2016; Liu, Li, Yang, \& Guo, 2017). At the same time, the operational state of the underground mines through which people and underground transport constantly move has also deteriorated.

In the world practice of developing steeply dipping ore deposits in cases when the similar problems arise, a solution is found by means of application the 
technology of strengthening the hanging wall rocks with cable bolts using special drilling units for fastening the mine workings (Bondarenko, Kovalevs'ka, \& Cherednychenko, 2010; Zhan \& Ye, 2014; Vivcharenko, Ruskykh, \&Sotskov, 2015). However, in the conditions of development of the Pivdenno-Bilozerske field, the designed cross section of drifts laid down in the hanging wall of the deposit is insufficient in the operation of drilling units in them for fastening the mine workings, and an increase in the section of drifts entails additional costs, which at the present moment makes the application of cable bolt strengthening quite doubtful.

The stability of the massif depends not only on the extent of rock pressure and seismic impact, but also on a number of geological factors related to the conditions of the ore body and host rocks' formation, the rocks being of the magmatic type. The geological structure of the Pivdenno-Bilozerske field is characterized by significant variation of the geological structure of the ore body and host rocks, their morphological composition, physical and mechanical properties, as well as elements of occurrence, which to different extents have an effect on the degrees of the extraction of the ore reserves. The difficulty is in the fact that the previously designed and currently applied technology of mineral resources extraction is not always capable of ensuring high efficiency in unstable mining and geological conditions. The issues of negative influence of complex mining and geological conditions, when developing the various types of mineral resources are covered in the works of domestic and foreign scientists (Timoshuk, Demchenko, \& Sherstuk, 2010; Villegas, Nordlund, \& Dahnér-Lindqvist, 2011; Lozynskyi, Saik, Petlovanyi, Sai, \& Malanchuk, 2018; Petlovanyi, Lozynskyi, Saik, \& Sai, 2018; Xia et al., 2019).

This paper further deals with the peculiarities of the ore body and host rocks occurrence in the Pivdenno-Bilozerske field, which form a very complex geological environment, and also their influence on the quality of the mined iron ores is assessed.

Research methods. An integrated analysis of the geological structure of the Pivdenno-Bilozerske field has been carried out in order to study the influence of the highly complicated geological structure of the ore deposit and host rocks on the technological aspects of extraction and quality of the mined iron ore. The influence of the geological environment on the ore quality can be observed only when mining the chambers of the first stage, surrounded by ore and rock massifs, without contacting with the backfill massif. The floor of $640-740 \mathrm{~m}$ was chosen in the research, the reserves of which are currently in the final stage of mining, where the most complete information is available on the parameters of mining the first stage of chambers .Along the ore deposit strike, according to exploration reports and excavation chambers' passports, the morphological composition of the hanging wall rocks, the hardness, the degree of fracturing, the angle of slope of the ore deposit and rocks, the thickness of the ore deposit were analysed. The data on the ore dilution was also analysed, according to the results of reserves' extraction from the chambers on contact with the hanging wall, as well as the places and volumes of rock collapse into chambers along the strike of ore deposit.

The values of subsidence and horizontal displacements with the development of stope works in the chambers were determined quarterly by surveying measurements in metering stations set in the drift of the hanging wall of the $740 \mathrm{~m}$ horizon, which made possible to define the nature of the rock massif displacement around the operating and laid chambers.

To visualize the data of the complex structural framework of Holovna ore deposit by digitizing its geological sections along the $305-840$ m horizons, a 3D-model has been developed with the use of the Autocad 2017 and 3D MAX software packages that makes it possible to present in detail the geological peculiarities of complex anomalous areas of the field.

\section{Research results and discussions.}

Problematic aspects of mining the ore reserves on contact with the hanging wall. In the process of ore extraction under effect of the rock pressure and depending on the geological peculiarities, the hanging wall rocks to different extents are collapsed into the stope space of the first stage chambers. With an increase in the mining depth, stress intensity of the rock massif increases, which in conditions of reduced stability of the rocks leads to their collapse into the chamber, as well as deterioration of the operational state of drifts in the hanging wall, which are located in the rocks at a distance of $20-25 \mathrm{~m}$ from the ore deposit contour (Khomenko, Kononenko, \& Danylchenko, 2016).

For effective planning of developing the mining operations, the ore deposit of the Pivdenno-Bilozerske field from the centre to the flanks is conventionally divided every other $30 \mathrm{~m}$ into surveying axes with the designations "c"- north, " 0 "- centre, "ю"- south, respectively, the stope chambers are also numbered in consecutive numbers, according to the surveying axis and the sequence of mining (for example, $1 / 7 \mathrm{~F}$, $2 / 7 ю$ ). At present, the main mining operations are carried out in the interval of $640-940 \mathrm{~m}$ depths, while 
the $640-740 \mathrm{~m}$ floor is at the final stage of mining, the $740-840 \mathrm{~m}$ floor is halfway mined-out, the $840-940 \mathrm{~m}$ floor is at the initial stage of mining.

As a result of quarterly instrumental observations of the state of the hanging wall drift of the $740 \mathrm{~m}$ horizon in the deposit area in the surveying axes from $10 \mathrm{c}$ to $10 \mathrm{r}$, which were performed in the period from July 24, 2007 to February 24, 2010, it was determined that the values of rock massif subsidence reached $70-195 \mathrm{~mm}$. The rate of the massif subsidence in certain areas has reached a value of $4-6 \mathrm{~mm} / \mathrm{month}$.

The character and forms of the rock pressure manifestations made it possible to establish that the disturbance of the stope space contours occurs in chambers located close to the hanging wall of the ore deposit. The chambers of the lying deposit wall are in the zone of reduced stress state conditioned by the protective (unloading) backfilling effect of the overlying mined-out and laid down chambers, as a result of which their structural elements, while located in the zone of reduced stresses, preserve their stability. Therefore, in the chambers close to the lying wall of the ore deposit, the disturbances of the stope space contours were practically not observed or there were minor dumps of the backfill out of bottoms above the mined-out and laid down chambers. A lower intensity of rock dilution in the lying wall in comparison with the hanging wall is also noted in the work (Petlovanyi, 2016).

In Fig. $1 a$, there is an extract from the mining operations plan on the $740 \mathrm{~m}$ horizon within the surveying axes $0-6 ю$, where the protrusions can be observed of already mined-out and laid down chambers beyond the limits of the ore deposit contour (indicated by red arrows). This testifies to the collapses of the hanging wall rocks into the excavation chambers, which dilute the ore, and the formation of an increased stress state in the hanging wall rocks, which leads to deterioration of a state of the drift of the $740 \mathrm{~m}$ horizon (Chistyakov, Ruskih, \& Zubko, 2012). The field investigations of the rock massif stress intensity, based on the fixation of visual signs of rock pressure manifestation in the drift of the hanging wall of the $740 \mathrm{~m}$ horizon, are evidence of an intensive process of balmstone formation. Shears and chipping off the rocks occur on the outcroppings of the drifts from the side of the minedout chambers and are external signs of increased massif stresses. These phenomena acquire the most evident character in the drifts of the hanging wall in the central and southern parts of the ore deposit. The consequences of rock pressure impact in the case of unstable rocks bedding in the hanging wall drift can be observed in the photograph (Fig. 1b).

Collapses of the hanging wall rocks lead to a number of consequences, which reduce the technicaland-economic indexes of the ore extraction from the chambers, from which the main ones should be distinguished, represented in Fig. 2.

As a result of collapses of the hanging wallrocks into the excavation chamber, there is an unexpected increase in the design volume of a chamber and in order to fill the newly formed cavities an additional amount of backfill mixture for imbedding is required, which leads to unforeseen expenses. The mined ore quality is reduced due to mixing of broken ore reserves and collapsed rock (quartzites, shale rock), in which the iron content varies at an average from 20 to $35 \%$. The ore's dilution by rock reduces its value, since there is a direct correlation between the iron content in the ore and its market selling cost. Simul-

б
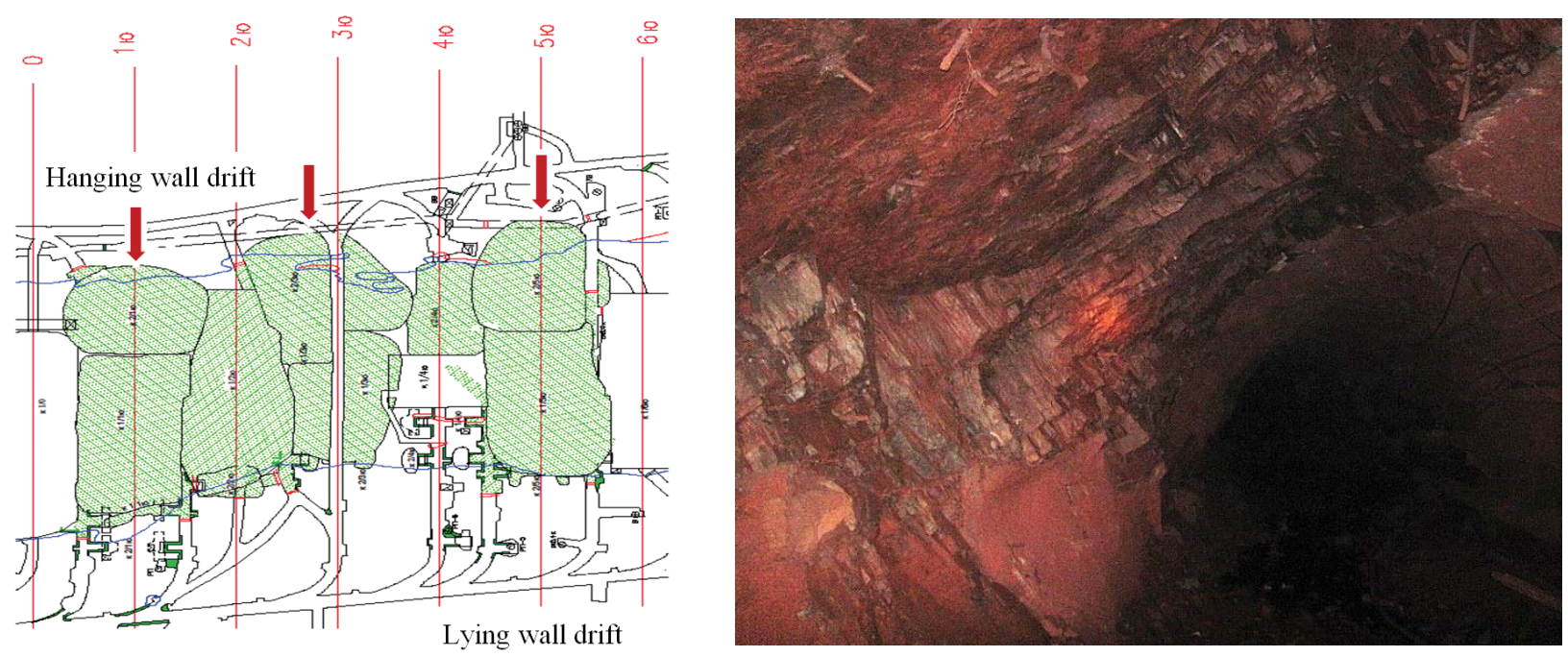

Fig. 1. Consequences of rock pressure manifestation in an unstable geological environment: (a) collapses of rocks of the hanging wall, when mining the ore from chambers; (b) chipping off and shear formation in the hanging wall drift of the $740 \mathrm{~m}$ horizon 


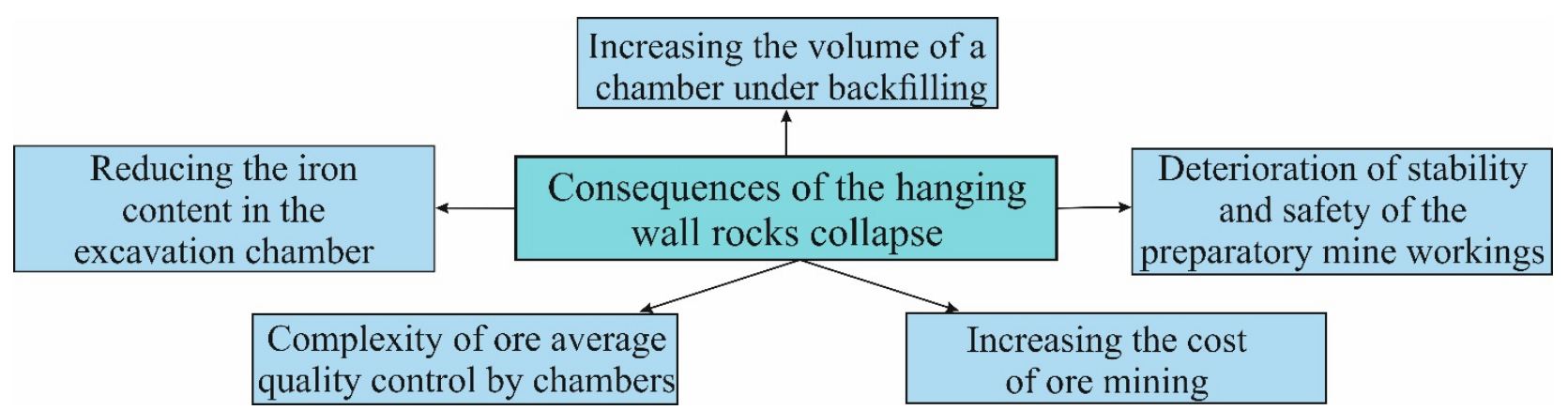

Fig. 2. Problematic aspects related to consequences of the hanging wall rocks collapse into the chamber

taneously with weakening of the quality of ore mined from the chamber, there arises the complexity of controlling its quality as a whole at the enterprise, as well as the necessity of mixing the streams of ore mass.

During the simultaneous mining, there may be 2 - 3 chambers within the floor, the iron content of which may be different, and to achieve the required iron content quality, the ore mass streams should be mixed. In case of major collapse of the rocks of the hanging wall into the stope space of the chamber, large rubble stones can plug up the funnels emptying the chambers, therefore, the ore production is suspended. In such cases, an additional grinding by explosion of rock rubble stones is applied, which affects the cost of ore mining. The problems of collapse of the rocks of the hanging wall reduce the stability and safe operation of mine workings of the hanging wall, since in the case of a high stress state and the presence of complex geological zones during rock collapse, these mine workings can be destroyed and the drift distance from the chamber contour, usually applied as $20-25 \mathrm{~m}$, can be insufficient.

Due to the increased influence of the hanging wall rocks on the mining technology, only the geological structure of the ore deposit and of the hanging was rocks, the formation of complex geological zones and their influence on the ore quality are analysed further in this paper.

Research into quality of mined iron ore in changing geological conditions along the strike of the deposit. The geological environment in which mining of iron ores reserves is conducted is represented directly by the ore body, as well as by host rocks of the lying and hanging walls. The detailed ore body characteristic along the strike of the Pivdenno-Bilozerske field indicates significant changes in both its physicalmechanical properties and its peculiarities of occurrence, as well as its morphological composition (Petlovanyi, Lozynskyi, Zubko, Saik, \& Sai, 2019). For convenient planning of mining operations, it is customary to divide the ore body of the PivdennoBilozerske field into the northern, central and southern parts.

The deposit is a banded iron formation curving inward in a western direction (from north-west to north-east) with a total sub-meridional strike of banded iron formations which include rich iron ores. On the southern flank the strike is north-western $\left(310^{\circ}\right)$, and from the middle of the ore deposit it changes to the north-eastern direction $\left(40^{\circ}\right)$. In the same direc-

Table 1. Characteristic of the geological environment and its properties in the $640-740 \mathrm{~m}$ floor

\begin{tabular}{|c|c|c|c|}
\hline \multirow{2}{*}{ Indicator } & \multicolumn{3}{|c|}{ Area along the strike of the ore body } \\
\hline & Northern part & Central part & Southern part \\
\hline Length of area, & 650 & 400 & 450 \\
\hline Hardness of rocks, $f$ & $14-15$ & $10-14$ & $6-9$ \\
\hline Angle of slope of the ore body, degree & $70-75$ & $67-70$ & $63-67$ \\
\hline $\begin{array}{l}\text { Angle of slope of the hanging } \\
\text { wall rocks, degree }\end{array}$ & $68-71$ & $67-68$ & $65-70$ \\
\hline \multirow{2}{*}{$\begin{array}{l}\text { Characteristic and thickness } \\
\text { of the ore body, } m\end{array}$} & \multirow{2}{*}{$\begin{array}{l}\text { Ore body is broken into a } \\
\text { number of veins, } 25-50\end{array}$} & \multicolumn{2}{|c|}{ Continuous ore body } \\
\hline & & $35-110$ & $50-160$ \\
\hline Fracturing & \multicolumn{2}{|c|}{ High, medium } & Medium \\
\hline Stability & \multicolumn{2}{|c|}{ Medium, low } & Medium \\
\hline $\begin{array}{l}\text { Morphological composition } \\
\text { of the hanging wall rocks }\end{array}$ & $\begin{array}{l}\text { Quartzites with hematite- } \\
\text { martite composition }\end{array}$ & $\begin{array}{l}\text { Quartzites with hematite- } \\
\text { martite composition,shale } \\
\text { rocks of quartz-peach-ser- } \\
\text { icitic composition }\end{array}$ & $\begin{array}{l}\text { Shale rocks of quartz-peach- } \\
\text { sericitic composition }\end{array}$ \\
\hline
\end{tabular}


tion, the angle of slope of ore deposit is changed, increasing its value from south to north - from $60-65^{\circ}$ to $70-80^{\circ}$. In the ore massif and host rocks, there is an intense fracturing and frequent replacement of rocks with varying strength characteristics within the technological parameters of the stope chambers. There are no disjunctive breaks, but separate fractures are disclosed in vertical and gentle planes with incidence angles of $10-20^{\circ}$ over the entire area of the field. The strike of vertical fractures prevails in the direction of $350^{\circ}$, and gentle fractures $-250-275^{\circ}$. The density of fractures varies from low (up to 2 fractures per meter) to very high (20 fractures per meter).The geological peculiarities of variability of the ore body and hanging wall rocks along the strike have been systematized and summarized in Table 1 .

The data in Table 1 indicates the significant variability of the geological structure and conditions of occurrence along the strike and in depth of the northern, central and southern ore deposit areas. Thus, from the northern ore body flank of the deposit to the southern flank, the values of the hanging wall rock hardness and the slope angle of the deposit decrease significantly. The morphological composition of the rocks changes, which is characterized by structure and texture, while the deposit thickness increases.

To visualize the data of the complex structural framework of Holovna ore deposit by digitizing its geological sections along the $305-840 \mathrm{~m}$ horizons, a 3D-model has been developed (Fig. 3). The model makes it possible to visually observe in axonometric projection the following geological peculiarities and forms of the ore body occurrence, as well as their change along the strike: the deposit thickness, the angle of slope and strike, the presence of folded contacts from the side of the hanging wall.

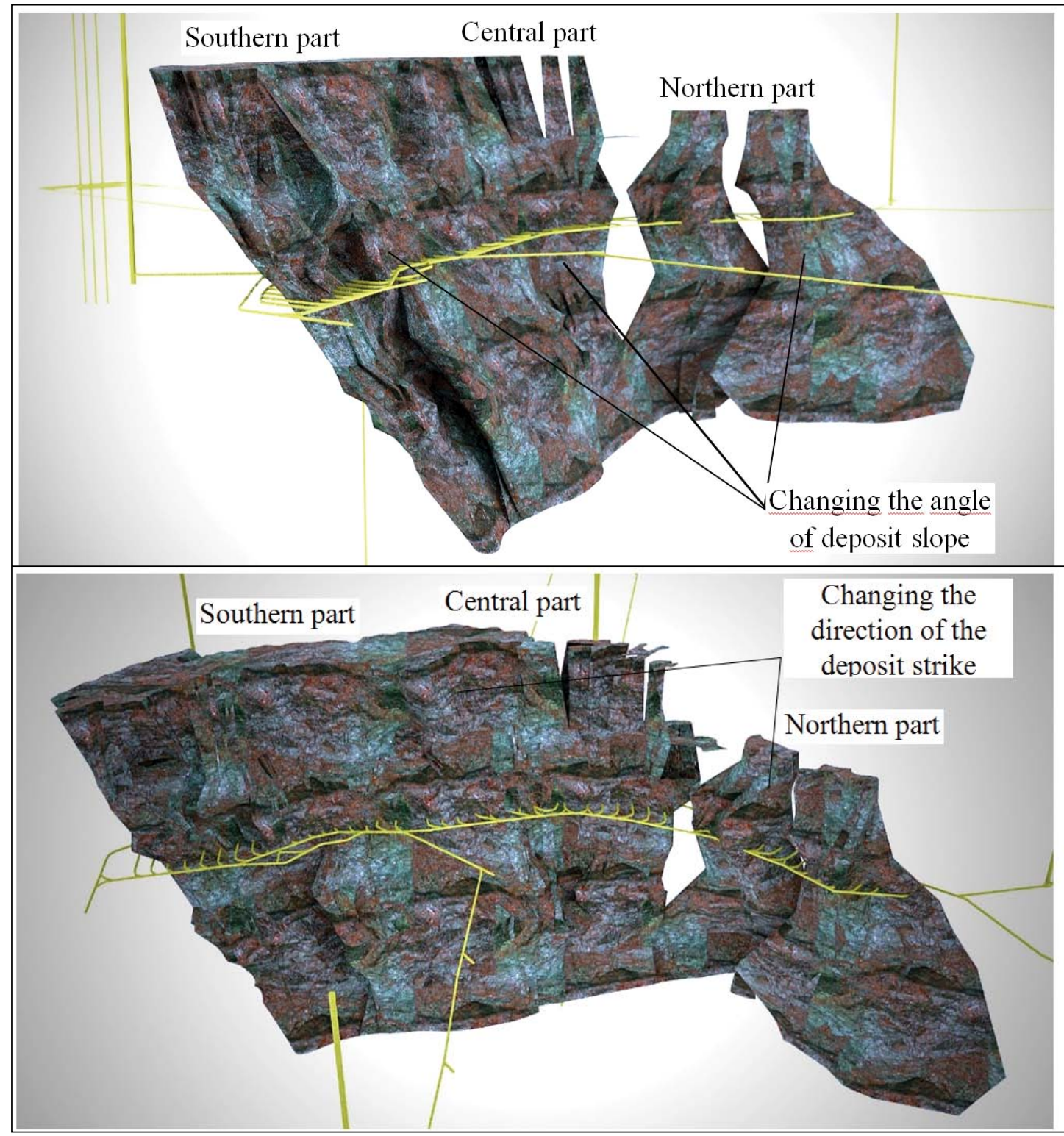

Fig. 3. 3D-model of the ore body visualization in the Pivdenno-Bilozerske field 
In order to determine the influence of changing geological conditions of the ore deposit and of the hanging wall rocks on the efficiency of iron ore mining, the parameters have been studied of chambers mining in different conditions of the ore deposit areas, varied by character - northern, central and southern (Fig. 4). The difference in the iron content in the mined ore relative to the initial iron content in massif of the chamber, according to the geological exploration data, has been defined as an indicative criterion of the influence of changing conditions on the production quality. The analysis provided for a comparison of the dynamics of changes in the average parameter of iron content $(\mathrm{Fe}, \%)$ in the mined ore of 5 mined-out chambers in the ore deposit parts with different geological conditions. part. Further on, a detailed analysis is performed of the reasons for the decrease in the iron content in each area. The decrease in the iron content in the mined ore within the northern area, despite the more favourable conditions for the stability of the hanging wall rocks, often complicated by a high level of fracturing, is primarily conditioned by the complex structure of the ore deposit. There is no serious collapse of the hanging wall rocks, represented by quartzite. The thickness of the ore deposit in the northern area, beginning with the surveying axis $7 \mathrm{c}$, is decreased sharply and, beginning with the axis $15 \mathrm{c}$, it splits into a set of ore bodies. The ore bodies are divided by quartzites, predominantly of hematite-martite composition, $7-20 \mathrm{~m}$ thick, with an iron content of $35-40 \%$. The dilution occurs in the northern deposit due to the fact that along the

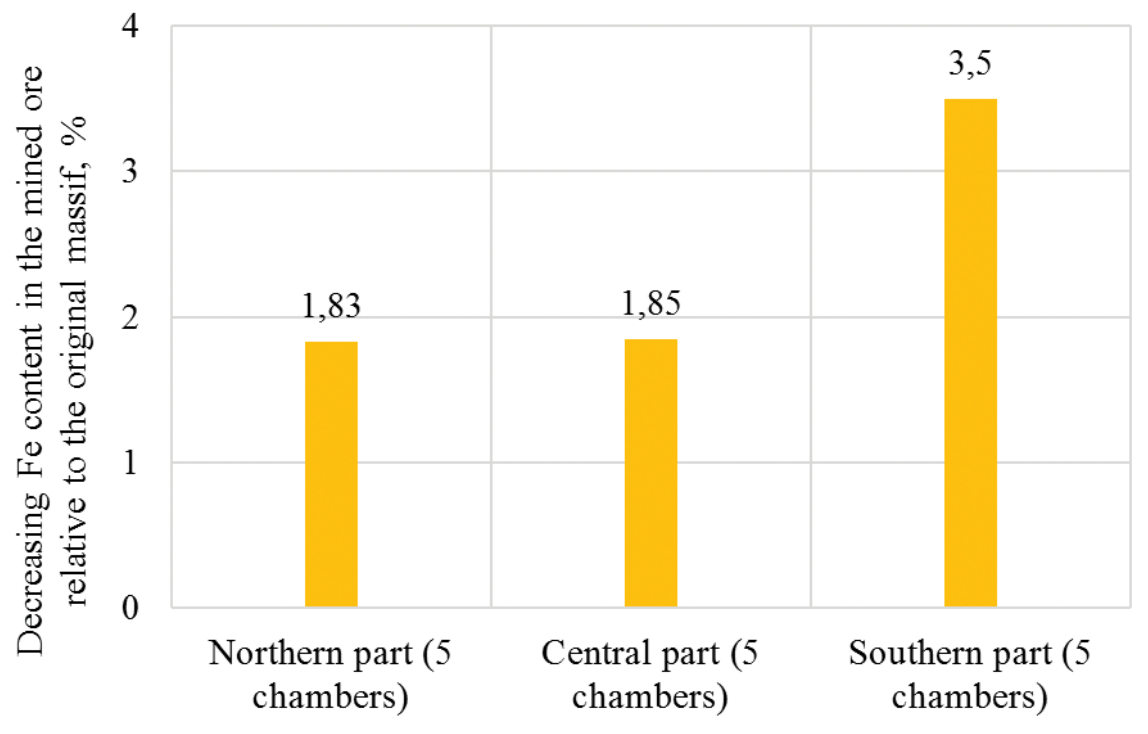

Ore deposit areas with different geological peculiarities

Fig. 4. Degree of the iron content variation in the mined ore relative to the original content in the massif with a change in the geological structure of the ore deposit along its strike

Besides, only the chambers of the first mining stage on contact with the hanging wall rocks were considered. Their side contacts are represented by the ore massif and the chambers, where a decrease was recorded in the iron content from the design content. The facts of the backfill massif collapse were excluded from the analysis. The width of each chamber was $30 \mathrm{~m}$, that is, the area of the inclined outcropping of the hanging wall rocks in the compared chambers was sufficiently alike and their height was $100 \mathrm{~m}$.

Analysing Fig. 4, it can be argued that the decrease in the iron content in the mined-out chambers, caused by penetration or collapse of the hanging wall rocks, is enhanced with a simultaneous change in its geological peculiarities and form of occurrence, as well as of the hanging wall rocks from the northern part of the ore deposit to the southern deposit thickness, one chamber is located across the strike.Therefore, within the deposit, both ore bodies and quartzite interlayers with a low iron content are delineated. Because of the explosive breaking of the hematite-martite ore reserves in the chamber, the quartzite veins are simultaneously beaten off, which leads to a decrease in the iron content.Moreover, in the northern part, the contact with host rocks often has a folded shape, sometimes there is an ore interstratification with host rocks, which, when the chamber is mined, influences the ore dilution.

The decrease in the iron content in the mined ore within the central deposit area is caused by the influence of geological factors, the form of occurrence of the ore deposit and rocks as a result of their collapse, since in this part there is a continuous thick deposit without quartzite interlayers. A decrease in the hard- 
ness in this deposit part along with a gradual replacement of quartzites with quartz-peach-sericitic shale rocks reduces the stability of the hanging wall rocks, and a change in the slope angle and direction of its strike from the north-eastern to the north-western direction changes and enhances the nature of the applied load on the stope chambers from the pressure of the overlying rock column. In the central deposit part, the collapses and dumps of rocks into the stope chambers are manifested. An increase in the horizontal chamber spacing (its length),caused by an increase in the thickness of the ore deposit up to $110 \mathrm{~m}$, where 2 - 3 chambers across the strike are located, also influences the stress state of the hanging wall rocks, which increases the probability of collapse and slabbing of the hanging wall rocks. For the northern part, the stope chambers with $25-40 \mathrm{~m}$ length are specific, for the central and southern parts $-40-60 \mathrm{~m}$. An important fact is the irregularity of the slope angle of the ore deposit with slope of the hanging wall rocks, which can serve as a concentrator of increased stresses in the hanging wall rocks.

The decrease in the iron content of the mined ore within the southern deposit part is characterized by a rapid change in hardness of the hanging wall rocks caused by the complete replacement of ferruginous quartzite with shale rocks, predominantly of the quartz-peach-sericitic composition with medium and coarse degree of schistosity, sometimes with interlayers of grey quartz and which are often folded. This type of rock has a lower iron content $(25-30 \%)$, a layered structure and cannot withstand significant outcrops in time. An increase in the deposit thickness to $160 \mathrm{~m}$ also leads to an increase in the horizontal spacing of chambers (their length) and an increase in stress intensity of the hanging wall rocks, as in the central deposit part.This southern deposit part is the most flattened compared to others, and its angle of slope decreases to $60-63^{\circ}$, the direction of the strike is similar to that in the central part, which also enhances the nature of the applied load on the stope chambers from the pressure of the hanging wall rocks. It appears that irregularity of the slope angle of the ore deposit with slope of the hanging wall rocks here acquires the most significant influence on the phenomenon of the shale rocks' collapse, because the difference in the slope angles of rocks and ore is at its maximum and reaches $7^{\circ}$. The frequent folded shape of the shale rocks and the irregularity of the slope angle can serve as a concentrator of increased stresses in the hanging wall. This is confirmed by the fact that the irregularity of the slope angles of ore and rocks was observed both in the northern (where quartzites occur) and in the central parts (where the hanging wall is represented by quartzites and shale rocks). However, at the same time, during the mining of chambers with irregular slope angles of ore and rocks in these deposit areas, a decrease in the iron content caused by collapse was of isolated occurrence. With the depth of the ore body occurrence, there is an increase in the zone of distribution of semi-resistant quartz-peachsericitic shale rocks with low hardness in the hanging wall rocks of the southern deposit part, which is represented in Fig. 5.

Given the negative tendency of influence of the shale rocks occurrence in the hanging wall of the southern deposit part, as well as a number of other geological factors mentioned above, during the transition of mining operations to $840-1040 \mathrm{~m}$ depth interval with the existing ore mining technology, a reduction of the hanging wall rocks stability should be expected, and, therefore, an increase in dilution as early as in the central part of the ore body.

The high intensity and density of collapse of the

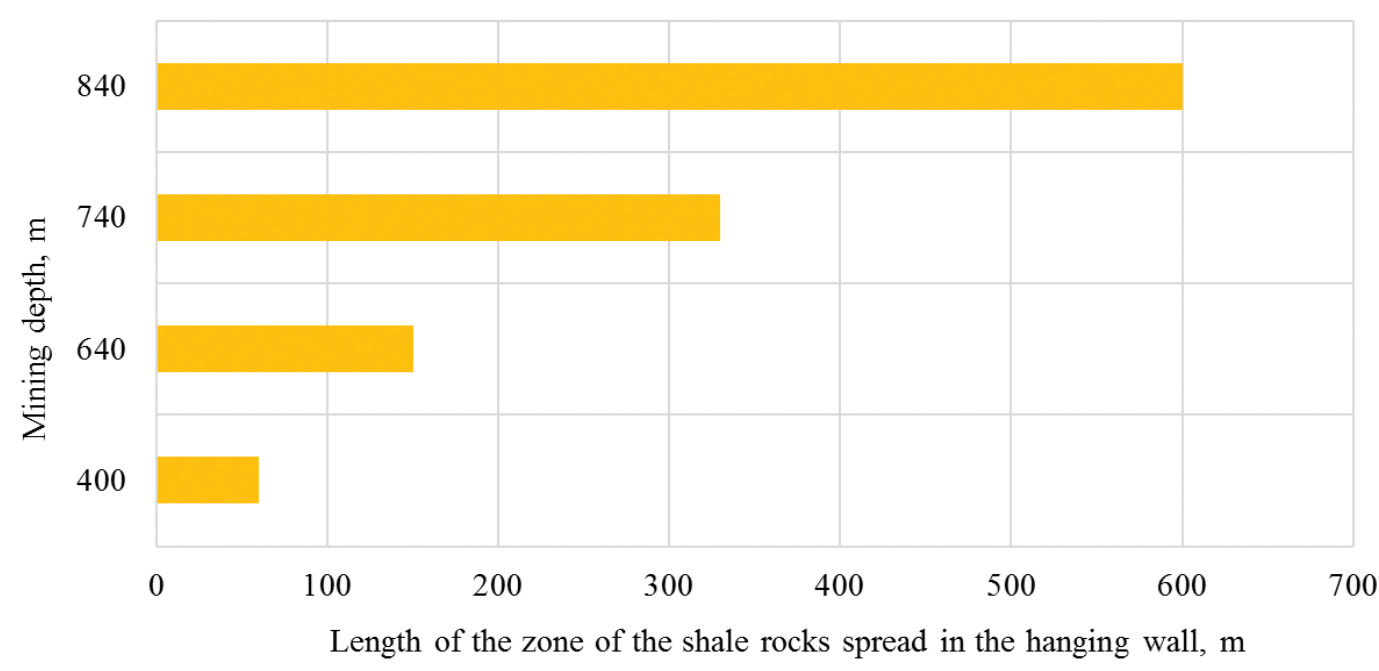

Fig. 5. Spread of the shale rocks zone in the hanging wall of the southern deposit part with the depth 
hanging wall rocks in the $640-740 \mathrm{~m}$ floor, which are shale rocks by $80 \%$, is observed in the zone covering almost the entire central and half of the southern ore deposit part with a length of $600 \mathrm{~m}$, which has a complex geological structure described above. The collapse phenomena were also observed earlier when mining the overlying floors: when mining $480-580$ and $548-640 \mathrm{~m}$ throughout the entire mine field from north to south, contour disturbances of the stope space were recorded in 62 chambers, of which $37(60 \%)$ were located in the central and southern parts of the ore deposit. In view of the sharp impact of geological factors and elements of the ore body and host rocks occurrence, the rock collapse manifestations and, as a result, dilution of high-grade ores, it can be argued that an anomalous geological zone is formed in this area along the strike of the ore body, distinguishing it from the northern deposit part. It should be noted that with the depth of the ore body occurrence, the length and character of this zone manifestation has a tendency to an increase, conditioned by the significant spread of shale rocks in the hanging wall of the deposit and an increase in the rock pressure impact. Within this zone, the influence of decrease in the slope angle and change in the strike direction are of greatest priority, and such geological factors as a decrease in hardness, morphology of the rocks, and deposit thickness increase this influence significantly.Under the conditions of a changing geological environment, it is necessary to study the nature and direction of action of gravitational forces on the stope chambers in the northern, central and southern parts, which are likely to be different.

The mining of iron ore in an anomalous geological environment should be based on a new scientific approach for ensuring the massif stability, which involves the consideration of a set of influencing mining and geological factors. Accounting for the above aspects will lay the foundations of technological optimization of ore deposits mining, which is required under the complex conditions of its central and southern parts.

In order to reduce the indicator of ore dilution with collapsed rocks, taking into account the complications of mining the chambers in the southern part of the $640-740$ and $740-840 \mathrm{~m}$ floors, the ore reserves located under the bottom of the inclined chambers (775 - $825 \mathrm{~m}$ floor) are customarily mined by chambers with lowered parameters in order to avoid large areas of outcropping of the unstable shale rocksheight $-50 \mathrm{~m}$, width - $15 \mathrm{~m}$ (Russkikh, Lapko, \& Zubko, 2012). Despite the lower delineation of the ore reserves by reduced chambers, their mining in the 775 - $825 \mathrm{~m}$ floor showed admissible dilution val- ues, that is, the collapses have decreased significantly. However, the question arises of mining the next lower $840-940 \mathrm{~m}$ floor, where the chambers of the first stage according to the project again have a height of $100 \mathrm{~m}$ and a width of $30 \mathrm{~m}$. This means that the phenomenon of the hanging wall rocks collapse, taking account of the experience of mining $640-740-840 \mathrm{~m}$ floors, is more likely to be repeated.

Therefore, for the chambers of the subsequent $840-1140 \mathrm{~m}$ floors, it is necessary to make new scientific and technical decisions in regards to changes in the geometric shapes of the stope chambers and their spatial location, improving the order of reserves' mining in terms of the ore deposit area, the rational order of breaking-out ore reserves in chambers with changing mining and geological conditions of field development.

Conclusions. When developing the Pivdenno-Bilozerske deposit of high-grade iron ores by the underground method in the depth range of $480-840 \mathrm{~m}$, problems arose in the stability of the natural and technogenic massif caused by rock pressure increasing with depth, the impact of explosive operations on the massif and the difference in geological conditions. This led to the collapse of hanging wall rocks and backfill into mined-out space of chambers in certain areas of the field. As a result of these phenomena, the ore dilution and deterioration of the operational state of underground mine workings occur.

The field investigations of the rock massif stress intensity, based on the fixation of visual signs of rock pressure manifestation in the drift of the hanging wall of the $740 \mathrm{~m}$ horizon, evidence an intensive process of balmstone formation. Shears and chipping off the rocks occur on the outcroppings of the drifts from the side of mined-out chambers and are external signs of increased massif stresses. These phenomena acquire the most evident character in the drifts of the hanging wall in the central and southern ore parts of the deposit. The character and forms of the rock pressure manifestations made it possible to establish that the disturbance of the stope space contours occurs in chambers located close to the hanging wall of the ore deposit.

Attention is focused on the causes and peculiarities of the consequences of collapse of hanging wall rocks during ore mining, which reduce the technical and-economic indexes of the ore extraction from the chambers. These include an increase in the volume of a mined-out space for backfilling; decrease in quality and increase in the cost of ore mining; complexity of quality control of iron-ore products in excavation chambers; diminution of the safety of preparatory mine workings in the hanging wall of the deposit. 
To visualize the data of the complex structural framework of Holovna ore deposit by digitizing its geological sections along the $305-840 \mathrm{~m}$ horizons, a 3D-model has been developed. The model makes it possible to visually observe in axonometric projection the following geological peculiarities and forms of the ore body occurrence, as well as their change along the strike: the deposit thickness, the angle of slope and strike, the presence of folded contacts from the side of the hanging wall.

We have studied the parameters of mining chambers under different changing geological conditions of the ore deposit and hanging wall rocks' occurrence - the northern, central and southern parts. The difference in the iron content in the mined ore relative to the initial iron content in the massif according to the geological exploration data has been defined as an indicative criterion of the influence of changing conditions on the production quality.

The reasons have been revealed which contribute to the collapse of the rocks and the subsequent decrease in the iron content of the mined ore in ore deposit areas differing by their characteristics. There is a dilution in the northern part due to the occurrence in the ore deposit of quartzite interlayers with a lower iron content.In the central area, the ore dilution is caused by collapse of rocks conditioned by a decrease in their hardness, a gradual replacement of quartzites with quartz-peach-sericitic shale rocks, and a change in the slope angle and direction of its strike from the north-east to the north-west. In the southern deposit part, the dilution is caused by rock collapse due to a rapid change in their hardness, complete replacement of ferruginous quartzite with shale rocks with a lower iron content, the smallest slope angle of the deposit, irregularity of slope angle of the ore deposit and the slope angle of hanging wall.

It has been established that the high intensity and density of collapse of the hanging wall rocks in the $640-740 \mathrm{~m}$ floor is observed in the zone covering almost the entire central and half of the southern ore deposit parts with a length of $600 \mathrm{~m}$, which are $80 \%$ shale rocks. In view of the sharp impact of geological factors and elements of the ore body and host rocks' occurrence, the rock collapse manifestations and, as a result, a dilution of high-grade ores, it can be argued that in the specified parts of the ore deposit an anomalous geological zone is formed, distinguishing it from the northern deposit part, and the manifestation of which will be increased with the depth of mining. Within this zone, the influence of decrease in the slope angle and change in the strike direction are of greatest priority, and such geological factors as a decrease in hardness, rocks morphology, deposit thick- ness increase this influence significantly.

To solve the problems of stability of the hanging wall rocks, it is recommended to study the nature and direction of action of gravitational forces on the stope chambers in the northern, central and southern parts, as well to search for scientific solutions in regards to changes in the geometric shapes of the stope chambers and their spatial location, improving the order of reserves mining in terms of the ore deposit area, the rational order of breaking-out of ore reserves in chambers with changing mining and geological conditions of field development.

Acknowledgement.The authors are grateful to Zubko Andrii Mykolaiovych, the technical director at PJSC “Zaporizhzhia Iron Ore Plant”, for his guidance in mining the main ore reserves in the $301-840 \mathrm{~m}$ floors, for valuable advice when preparing this paper. The studies have been conducted under the framework of performing the scientific work of the "Young scientists of Dnipropetrovsk region" competition with support of the Dnipropetrovsk Regional State Administration.

\section{References}

Bondarenko, V., Kovalevs'ka, I., \& Cherednychenko, Y. (2010). Substantiation of design and installation technology of tubular rock bolts by explosive method. New Techniques and Technologies in Mining, 9-14. https://doi.org/10.1201/b11329-3

Chistyakov, E., Ruskih, V., \& Zubko, S. (2012). Investigation of the geomechanical processes while mining thick ore deposits by room systems with backfill of worked-out area. Geomechanical Processes During Underground Mining - Proceedings of the School of Underground Mining, 127-132. https:// doi.org/10.1201/b13157-23

Emad, M.Z., Vennes, I., Mitri, H., \& Kelly, C. (2014). Backfill practices for sublevel stoping system. Mine Planning and Equipment Selection, 391-402. https://doi.org/10.1007/978-3-319-02678-7 38

Forster, K., Milne, D., \& Pop, A. (2007). Mining and rock mass factors influencing hanging wall dilution. Rock Mechanics: Meeting Society's Challenges and Demands, 1361-1366. https://doi. org/10.1201/noe0415444019-c169

$\mathrm{Fu}, \mathrm{Z}$. (2018). The mechanism of imported iron ore price in China. Modern Economy, 09(11), 1908-1931. https://doi.org/10.4236/me.2018.911120

Gnatush, V.A. (2009). Mining and metallurgical complex of Ukraine (numbers, facts, comments). Kyiv, Ukraine: Naukovadumka, $732 \mathrm{p}$.

Henning, J.G., \& Mitri, H.S. (2007). Numerical modelling of ore dilution in blasthole stoping. International Journal of Rock Mechanics and Mining Sciences, 44(5), 692-703. 
https://doi.org/10.1016/j.ijrmms.2006.11.002

Khomenko, O., Kononenko, M., \& Danylchenko, M. (2016). Modeling of bearing massif condition during chamber mining of ore deposits. Mining of Mineral Deposits, 10(2), 40-47. https:// doi:10.15407/mining 10.02.040

Kononenko, M., Petlovanyi, M., \& Zubko, S. (2015). Formation the stress fields in backfill massif around the chamber with mining depth increase. Mining of Mineral Deposits, 9(2), 207-215. https://doi. org/10.15407/mining09.02.207

Kuz'menko, A., Furman, A., \& Usatyy, V. (2010): Improvement of mining methods with consolidating stowing of iron-ore deposits on big depths. New Techniques and Technologies in Mining, 131136. https://doi.org/10.1201/b11329-22

Kuzmenko, O., \& Petlovanyi, M. (2015). Substantiation the expediency of fine gridding of cementing material during backfill works. Mining of Mineral Deposits, 9(2), 183-190. https://doi.org/10.15407/ mining09.02.183

Li, L. (2013). A new concept of backfill design - application of wick drains in backfilled stopes. International Journal of Mining Science and Technology, 23(5), 763-770. https://doi.org/10.1016/j. ijmst.2013.08.022

Liu, G., Li, L., Yang, X., \& Guo, L. (2017). Numerical analysis of stress distribution in backfilled stopes considering interfaces between the backfill and rock walls. International Journal of Geomechanics, 17(2), 06016014. https://doi.org/10.1061/(asce) gm.1943-5622.0000702

Lozynskyi, V., Saik, P., Petlovanyi, M., Sai, K., \& Malanchuk, Y. (2018). Analytical research of the stress-deformed state in the rock massif around faulting. International Journal of Engineering Research in Africa, (35), 77-88. https://doi. org/10.4028/www.scientific.net/jera.35.77

Peregudov, V.V., Gritsina, A.E., \& Dragun, B.T. (2010). Current state and future development of iron-ore industry in Ukraine. Metallurgical and Mining Industry, 2(2), 145-151.

Petlovanyi, M. (2016). Influence of configuration chambers on the formation of stress in multi-modulus mass. Mining of Mineral Deposits, 10(2), 48-54. https:// doi.org/10.15407/mining 10.02.048

Petlovanyi, M.V., Lozynskyi, V.H., Saik, P.B., \& Sai, K.S. (2018). Modern experience of low-coal seams underground mining in Ukraine. International Journal of Mining Science and Technology, 28(6), 917-923. https://doi.org/10.1016/j. ijmst.2018.05.014

Petlovanyi, M.V., \&Medianyk, V.Y. (2018). Assessment of coal mine waste dumps development priority. Naukovyi Visnyk Natsionalnoho Hirnychoho Universytetu, (4), 28-35.https://doi.org/10.29202/ nvngu/2018-4/3

Petlovanyi, M., Kuzmenko, O., Lozynskyi, V., Popovych, V., Sai, K., \& Saik, P. (2019). Review of man-made mineral formations accumulation and prospects of their developing in mining industrial regions in Ukraine. Mining of Mineral Deposits, 13(1), 24-38. https://doi.org/10.33271/ mining 13.01.024

Petlovanyi, M., Lozynskyi, V., Zubko, S., Saik, P., \& Sai, K. (2019). The influence of geology and ore deposit occurrence conditions on dilution indicators of extracted reserves. Rudarsko Geolosko Naftni Zbornik, 34(1), 83-91. https://doi.org/10.17794/ rgn.2019.1.8

Russkikh, V.V., Lapko, V.V., \& Zubko, S.A. (2012). Development and adoption of new technical decisions for development of Yuzhno-Belozerskoye ore deposit under difficult mining and geological conditions. Naukovyi Visnyk Natsionalnoho Hirnychoho Universytetu, (5), 34-38.

Shatokha, V. (2015). The sustainability of the iron and steel industries in Ukraine: challenges and opportunities. Journal of Sustainable Metallurgy, 2(2), 106-115. https://doi.org/10.1007/s40831015-0036-2

Timoshuk, V., Demchenko, J., \& Sherstuk, Y. (2010). The role of natural and technogenic components in failure of geomechanical stability of the territories which are in the influence zone of mining objects. New Techniques and Technologies in Mining, 189-192. https://doi.org/10.1201/b11329-31

Urli, V., \&Esmaieli, K. (2016). A stability-economic model for an open stope to prevent dilution using the ore-skin design. International Journal of Rock Mechanics and Mining Sciences, (82), 71-82. https://doi.org/10.1016/j.ijrmms.2015.12.001

USGS - United States Geological Survey. (2018). Mineral Resources Program. [online]. Retrieved from: http://minerals.usgs.gov/

Villegas, T., Nordlund, E., \&Dahnér-Lindqvist, C. (2011). Hanging wall surface subsidence at the Kiirunavaara Mine, Sweden. Engineering Geology, 121(1-2), 18-27. https://doi. org/10.1016/j.enggeo.2011.04.010

Vivcharenko, O., Ruskykh, V., \&Sotskov, V. (2015). Determination of roof support parameters for overworking roadway during adjacent seams at extraction in the conditions of Western Donbas mines. Mining of Mineral Deposits, 9(1), 35-42. https://doi.org/10.15407/mining09.01.035

Xia, K., Chen, C., Zheng, Y., Zhang, H., Liu, X., Deng, Y., \& Yang, K. (2019). Engineering geology and ground collapse mechanism in the Chengchao iron-ore mine in China. Engineering Geology, (249), 129-147. https://doi.org/10.1016/j. enggeo.2018.12.028

Zhan, F.L., \& Ye, P. (2014). Construction techniques and mechanism of pre-anchoring fissured stope hanging wall by fully-grouted cable bolts. Applied Mechanics and Materials, (580-583), 283-286. https://doi.org/10.4028/www.scientific. net/amm.580-583.283 